\title{
Diyabetik hastalarda ayak problemlerinin yönetimi ve vasküler patolojilere yaklaşım
}

\section{Management of foot problems in diabetic patients and approach to vascular pathologies}

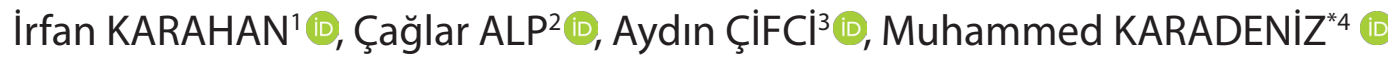 \\ ${ }^{1}$ Yenimahalle Eğitim Araştırma Hastanesi İç Hastalıkları Kliniği, Ankara, Türkiye \\ ${ }^{2}$ Hitit Üniversitesi Çorum Eğitim Araştırma Hastanesi Kardiyoloji Kliniği, Çorum, Türkiye \\ ${ }^{2}$ Kırıkkale Üniversitesi Tıp Fakültesi İç Hastalıkları Anabilim Dalı, Kırıkkale, Türkiye \\ ${ }^{4}$ Kırıkkale Üniversitesi Tıp Fakültesi Kardiyoloji Anabilim Dalı, Kırıkkale, Türkiye
}

\section{Öz}

Diyabet prevalansı tüm dünyada giderek artmakta ve büyük bir halk sağlığı problemine dönüşmektedir. Diyabetin komplikasyonları hastalığın kendisinden daha büyük problemlere neden olmaktadır. Bir diyabetli hastanın ayağında ülser gelişmesi hastalarda ciddi morbidite ve hatta mortaliteye neden olabilmekte, ayrıca sağlıkgiderlerinin aşırı derecede artması ile sonuçlanmaktadır. Dünya genelinde tüm sağlık harcamalarının yaklaşık 1/6'sı diyabet ve onun getirdiği problemler nedeniyledir. Diyabet hastalarının hayatları boyunca \%12-15 oranında diyabetik ayak ülseri geliştirme riski bulunmaktadır ve diyabetlilerin hastaneye yatış nedeninin 1/4'ünü oluşturmaktadır. Ampütasyon insidansı 6-8/1000 DM yıl civarındadır ve travma dışı ampütasyonların dünyada en sık nedeni (\%50'den fazlası) diyabettir. Bu hastalarda hem vasküler problemler hem de kan şekeri düzensizliğinin etkisiyle küçük bir enfeksiyon odağı günler içinde hızla sepsise ilerleyip uzuv kaybına yol açabilmektedir. Bu kadar sık karşılaşılan bir problemin önlenmesi en önemli halk sağlığı konularından biridir. Tüm önlemlere rağmen diyabetik bireyler ayak problemi ile karşılaşılmışsa, problem erkenden ortaya konulmalı ve diyabetik ayak ekibi olarak gerekli müdahaleler vakit kaybetmeden yapılmalıdır.

Anahtar kelimeler: aiyabetik ayak; ülser; Wagner sınıflaması; korunma; tedavi

\section{Abstract}

The prevalence of diabetes is increasing all over the world and is becoming a major public health problem. The complications of diabetes are causing more problems than the disease itself. The development of ulcers on the feet of a diabetic patient can cause serious morbidity and even mortality in patients, resulting in an excessive increase in health expenditure. About one-sixth of all health spending worldwide is caused by diabetes and its problems. Diabetic patients are at risk of developing diabetic foot ulcers by $12-15 \%$ throughout their lives and account for $1 / 4$ of the diabetic 's hospitalization. The incidence of amputation is around 6-8 / 1000 DM year and the most common cause of non-traumatic amputations in the world (more than 50\%) is diabetes. In these patients, due to both vascular problems and blood sugar irregularity, a small area of infection may rapidly develop sepsis and lead to limb loss in days. Preventing such a common problem is one of the most important public health issues. If, despite all precautions, a diabetic individual has encountered a foot problem, the problem should be addressed early and the necessary interventions as a diabetic foot team should be done without losing time.

Keywords: diabetic foot; ulcer; Wagner classification; prevention; treatment

Sorumlu Yazar*: Muhammed Karadeniz, Kırıkkale Üniversitesi Tıp Fakültesi Kardiyoloji Anabilim Dalı, Kırıkkale, Türkiye E-posta: drkaradeniz36@gmail.com

ORCID: 0000-0003-2432-0378

Gönderim: 07.08.2017 Kabul : 14.08.2017

Doi: $10.18663 /$ tjcl.333137 


\section{Giriş ve Etiyopatogenez}

Diyabet sıklı̆ı ve karşılaştığımız komplikasyonlar obezitenin de artması ile birlikte giderek artmaktadır. Diyabetli bir hastanın ayağında oluşan her türlü lezyon diyabetik ayak problemi olarak adlandırılabilir. Diyabet hastalarııı \%12-15'i hayatlarının bir döneminde diyabetik ayak ülseri gelişme riskiyle karşı karşıya kalmaktadır. Diyabetik ayak ülserleri hastanın yaşam kalitesinde ciddi bozulmalara yol açmakta, alt ekstremite ampütasyonlarına neden olabilmekte ve mortalite oranlarında da önemli bir artışa yok açmaktadır. Non-travmatikalt ekstremite ampütasyonlarının yarısından daha çoğu diyabete bağlı ayak problemleri nedeniyledir. Diyabetik ayak ülserleri diyabetin geç komplikasyonlarından olan periferik nöropati, periferik arter hastalı̆̆ı ve ayak travmalarına bağlı olarak oluşmaktadır. Diyabetik ayak sorunlarının oluşması için iki veya daha fazla risk faktörünün bir arada bulunması gerekir (Tablo 1). Hastaların büyük çoğunda diyabetik periferik nöropati merkezi bir rol oynamaktadır. Diyabet süresi 10 yılı aşan tip 2 diabetes mellitus hastalarının \%50'sinden fazlasında nöropati vardır ve bu da ayakta ülser gelişme riskini artıran en önemli faktördür [1,2].

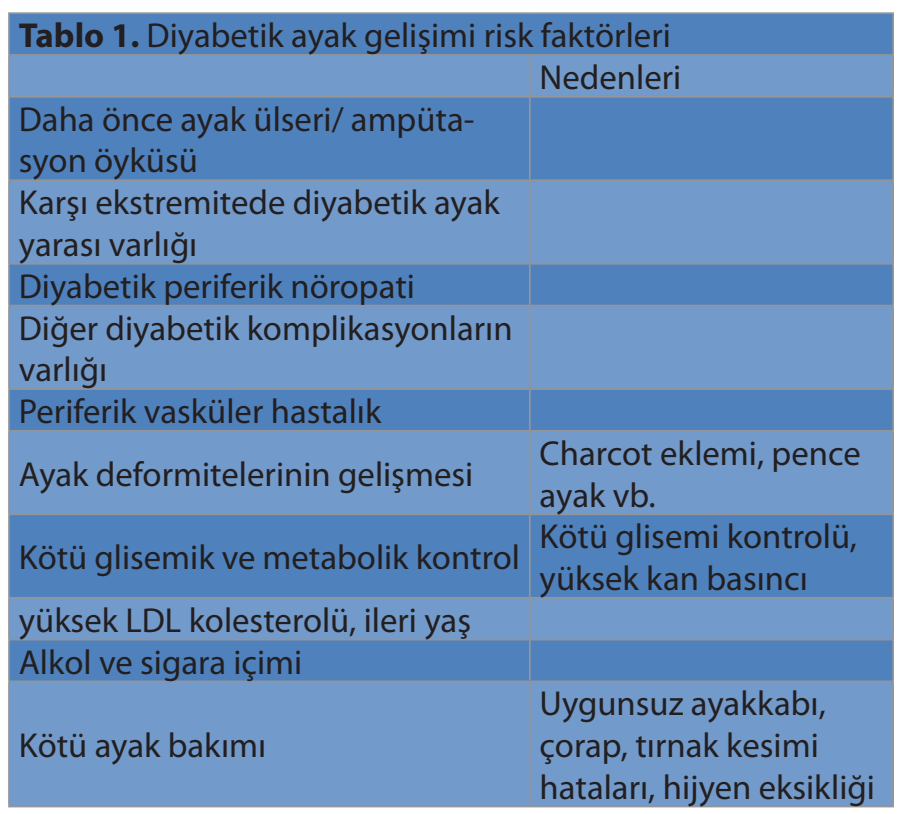

Nöropatiye bağlı olarak, doku bütünlüğünü bozmaya neden olabilecek minör bir travma ülser gelişimini kolaylaştırmaktadır. Motor nöropatiye de bağlı olarak intrensek kaslarda atrofi oluşmakta, kısıtlı eklem hareketleri nedeniyle de deformite oluşum süreci hızlanmaktadır. Deformiteler sonucunda yük dağılım dengesi bozulmakta ve buna bağlı oluşan mekanik travmalarla birlikte metatars başları altına yerleşimli kallus oluşmaktadır. Kallus gelişimi ile birlikte kanama ve iskemi gelişen dokuda zamanla yüzeyel ülserler gelişmektedir. Kontrolsüz hiperglisemi ve iskemi, tekrarlayan travmalar ile birlikte derin yerleşimli ülser oluşumunu kolaylaştırmakta ve enfeksiyonlara zemin hazırlamaktadır.
Hastaneye geç başvurma, saptandığında tedavi sürecinde geri kalınmışolması, hiperglisemi nedeniyle lökositlerdemigrasyon, adhezyon, fagositozveopsonizasyonunun bozulması diyabetik ayak enfeksiyonlarının ilerlemesini kolaylaştırmaktadır. Hasta ilk görüldüğünde yaranın temizlenmesi, nekrotik dokunun debridmanı yapılmalı ve yaranın kemiğe ulaşıp ulaşmadığının araştırılması gerekmektedir. Tüm bu aşamalar düzenli bir şekilde uygulanmadığı takdirde, diyabetik ayak enfeksiyonları oluşmaktadır [1,3].

\section{Tanım ve Sınıflandırma}

Diyabetik ayak enfeksiyonlarında etiyoloji değişken, patolojik değişiklikler farklı, metabolik özellikler farklı, ülserler homojen değildir. Bu nedenle diyabetik ayak sınıflandırma sistemlerine gerek vardır. PEDIS, SAD sınıflaması, Texas Üniversitesi sınıflaması, Forrest ve Gamberg-Nielson sınıflaması, DEPA, DUSS, MAID sınıflaması gibi daha pek çok sınıflama sistemi kullanılmıştır. Günümüzde pratik olduğu için Wagner sınıflaması yaygın olarak kullanılmaktadır (Tablo 2) [4,5].

Tablo 2. Diyabetik ayak ülser gelişimine yol açan durumlar
Doğrudan travma (delici bir obje üzerine basmak, yanlış
tırnak kesimi)
Tekrarlayan uygunsuz basınç (ayakkabı ı vurması)
Sürekli uygunsuz basınç (yatağa bağımlı hastada topuk
sürtmesi)
Yanık, böcek sokmaları ve hayvan ısırmaları
Eklem hareketlerinde azalma
Ayakta nasırların uygunsuz tedavisi
Kötü ayak hijyeni, ayakta şekil bozukluğu

Klinik değerlendirmede enfeksiyon varlığı (ısı artışı, kızarıklık, hassasiyet, yüksek ateş, pürülan akıntı, kötü koku) mutlaka gözetilmelidir. Diyabetik hastalarda ayak problemleri çeşitli yöntemlerle değerlendirilebilir (Tablo 3) $[4,5]$.

$\begin{array}{ll}\text { Tablo 3. Diyabetik ayak sınıflaması (Wagner sınıflaması) } \\ \text { Grade } 0 & \begin{array}{l}\text { Ülser yok, yüksek riskli1 ayak } \\ \text { Yüzeyel ülser (cilt altı yağ dokusuna penetrasyon } \\ \text { yok, yüzeyel enfeksiyon bulgusu, sellülit olabilir, } \\ \text { yara bakımı ile kolay iyileşir) }\end{array} \\ \text { Grade } & \begin{array}{l}\text { Subkutan dokuya invaze ülser (cilt altı yağ doku- } \\ \text { su, tendon, eklem kapsülü etkilenmiş; ligamente, } \\ \text { kasa, kemiğe penetrasyon ve abse yok) }\end{array} \\ \text { Grade } & \begin{array}{l}\text { Selülit ve apse formasyonu ile birlikte derin ülser } \\ \text { (sıklıkla osteomyelit mevcut) }\end{array} \\ \text { Grade } & \begin{array}{l}\text { Lokalize gangren (gangren dışındaki diğer } \\ \text { bölümler kurtarılabilir) }\end{array} \\ \text { Grade } & \begin{array}{l}\text { Tüm ayağı tutan yaygın gangren (ekstremite } \\ \text { ampütasyonu gerekebilir) }\end{array} \\ \text { Grade } & \text { 'Nasır, his kusuru, deformite, kötü glisemik kontrol, yaşılık, yalnız } \\ \text { yaşama, kas iskelet sistemi ve nörolojik sorunlar, alkolizm, görme } \\ \text { bozukluğu, psikiyatrik ilaç kullanımı vs. }\end{array}$




\section{Laboratuvar}

Hastalar öncelikle enfeksiyon yönünden değerlendirilmeli, bu amaçla akut faz reaktanları olan beyaz küre, c-reaktif protein(CRP) , Eritrosit sedimentasyon hızı(ESR) mutlaka bakılmalıdır. Glisemik durumun değerlendirilmesi ve kan şekeri regülasyonu amacıyla HBA1C ve kan şekeri takipleri; organ fonksiyonlarını görmek için üre, kreatinin, aspartat aminotransferaz, alanin aminotransferaz; nütrisyon durumunu değerlendirmek için albümin, tiroid fonksiyonlarının değerlendirilmesi için tiroid stimülan hormon (TSH) bakılması önemlidir. Yara kültürü, eğer akıntılı yara yoksa derin doku kültürü alınması, yüksek ateşi varsa kan kültürü alınması gereklidir. ESR yüksekliği özellikle osteomiyeliti değerlendirmek için önemlidir, ayrıca direkt grafi ve prob testi ile de (probun ciltten kemiğe kadar kolayca ulaşması osteomiyelit düşündürür) osteomiyelit tanısını koymada yol göstericidir. Emin olamadığımız olgularda manyetik rezonans görüntüleme (MRG) büyük ölçüde tanı koydurucudur [6].

\section{Diyabetik ayakta vasküler patolojilere yaklaşım}

Diyabetik ayak yaralarının periferik nöropati, periferik arter hastalığı ve enfeksiyonun birlikteliğinden meydana geldiği bilinmektedir [7]. Diyabetik ayak yarası bulunan hastaların yaklaşık yarısına periferik arter hastalığı (PAH) eşlik eder $[8,9]$. PAH'da etyolojik sebep "ateroskleroz" dur. Diyabetik hastalarda ateroskleroz genellikle daha erken yaşlarda başlar arterin birden çok segmentinde tutulum gösterir ve daha çok distal periferik arterleri etkiler. Ateroskleroz PAH'ta mikro ve makroanjiyopatiye sebep olur. Mikroanjiopati nedeniyle bu hastalarda mikrosirkülasyon bozulur ve dokulara yeterli oksijen ulaştırılamaz, bu da ayakta ülser oluşumuna yol açar.

PAH genellikle alt ekstremitelerde görülür. Hastalık başlangıçta ağıı ile kendini gösterir. Bu dönemde tıkalı arterler yüzünden distale kollaterallerle giden az miktardaki kan istirahatte extremiteyi beslerken eforla artan kan ihtiyacını karşılayamaz ve ilk önce kladikasyo intermitant (yürüme ağrısı) ortaya çıkar. Hastalık ilerledikçe hastanın ayağının ön bölümünde özellikle geceleri artan istirahat ağrısı olur.

Diyabetik ayakta ayrıntılı vasküler değerlendirme gangren ile gelen hastalar başta olmak üzere tüm hastalarda gereklidir (Tablo 4). En önemli tanı yöntemi fizik muayenedir. İyi bir anamnez ve fizik muayene ile tanı rahatıkla konulabilir [10]. Fizik muayenede $\mathrm{PAH}^{\prime}$ ın olduğu tarafta cilt parlak görülür, kıllar dökülmüş, tırnaklar kalınlaşmış ve ekstremite soğuk ve soluk görünümdedir. Ülserler genellikle parmaklar, tibia kenarları ve bası noktalarında oluşur. FM'de PAH'dan şüphelenilen hastalarda ilk olarak Ankle-Brakial İndeks (ABI) ölçülmelidir. $A B I \% 95$ duyarlılık, \%99 özgüllüğe sahip bir tanı yöntemidir. ABI'nın 1.0-1.3 arası olması normal kabul edilir, $\leq 0.9$ olması $P A H$ açısından tanı koydurucudur. Daha sonra tanı yöntemlerinden non-invaziv olan arterial doppler ultrasonografi ve gereken hastalarda dijital substrakt anjiyografi (DSA) yapılmalıdır. DSA bu hasta grubunda altın standart olarak kabul edilmektedir. Periferik arter hastalarında distal arter nabızları alınabilir olsa bile aterosklerotik lezyonlardan kaynaklanan mikroemboliler diyabetik hastalarda kritik damar iskemisine neden olabilmektedir. Bu tip lezyonlar doppler ve fizik muayenede tespit edilemeyebilir. Bundan dolayı diyabete bağlı vasküler patoloji düşünülüyorsa DSA ön planda düşünülmelidir [11].

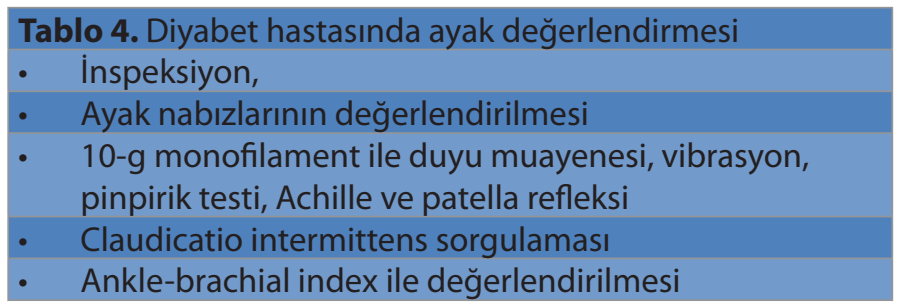

Hastalarda istirahat ağrısı veya ayakta gangren veya nekroz gelişmesi kritik bacak iskemisi olarak isimlendirilir. Kritik bacak iskemisi geliştikten sonra bu hastalarda çoğu zaman cerrahi veya perkütan yolla revaskülarizasyon gereklidir. Revaskülarizasyon için standart tedavi femorodistal bypass'tır. Diyabetik hastalarda komormiditenin yüksek olması nedeniyle cerrahi dışında uygun vakalarda anjiyoplasti, stent implantasyonu, endarterektomi, subintimal anjiyoplasti gibi yöntemler de kullanılmaktadır. Son yıllarda teknolojinin gelişmesiyle daha ince kateterlerin ve kılavuz tellerin kullanılmaya başlanmasıyla daha distal damarlara da müdahale imkanı vermektedir. Ayrıca damar yapısına daha uygun balon ve stentlerin geliştirilmesiyle işlem süreleri kısalmış ve komplikasyon oranları ciddi derecede düşmüştür. Hasta açısından daha az travmatik olduğundan ve hastanede yatış süresini kısalttığından dolayı perkütan girişim oranı ve tedaviye uyum giderek artmaktadır. Kritik bacak iskemisi erken dönemde tespit edilip revaskülarize edilirse amputasyon riskini ve ampütasyon seviyesini azaltabilir. Eğer ayağın revaskülarizasyonu sağlanamazsa iskemi daha da artıp ülser ve gangren oluşmasına neden olur. PAH tek başına ülser oluşmasına neden olmaz, genellikle eşlik eden bir travma sonucu yara oluşur.

Tedavinin amacı ağrısız, fonksiyonunu kaybetmemiş bir ekstremite, yaraların kapanması ve yaşam kalitesinin düzelmesidir [12].

\section{Sonuc}

Sadece kan şekeri regülasyonu ve enfeksiyonla mücadele değil vasküler problemlerin de göz önünde bulundurularak bu problemlerin hızlı bir şekilde çözüme kavuşturulması gerekmektedir. Bu nedenle diyabetik ayak problemlerinin yönetimi bir ekip işidir ve bu ekipte dahiliye, endokrinoloji, enfeksiyon hastalıkları uzmanı ve ortopedistin yanısıra kardiyolog ve kalp-damar cerrahı da mutlaka olmalıdır. 


\section{Çıkar çatışması / finansal destek beyanı}

Bu yazıdaki hiçbir yazarın herhangi bir çıkar çatışması yoktur. Yazının herhangi bir finansal desteği yoktur.

\section{Kaynaklar}

1. Diyabetik Ayak Sorunları. Türkiye Endokrinoloji ve Metabolizma Derneği Diabetes Mellitus ve Komplikasyonlarının Tanı, Tedavi ve İzlem Kılavuzu. 2016;8. baskı:149-57.

2. Apelqvist J, Bakker K, Houtumvan W. H, Schaper N. C. Practical guidelines on the management and prevention of the diabetic foot. 2008:24:181-7.

3. Yan J, Li S, Li S. The role of the liver in sepsis 2014; 33: 498-510.

4. Mete B. Sepsiste böbrek ve karaciğer. İ.Ü. Cerrahpaşa Tıp Fakültesi Sürekli Tıp Eğitimi Etkinlikleri Güncel Bilgiler Işığında Sepsis Sempozyum Dizisi 2016: 51: 35-43.

5. Saltoğlu N, Kılıçoğlu Ö, Baktıroğlu S, Oşar Siva Z et al. Diyabetik ayak yarası ve enfeksiyonunun tanısı, tedavisi ve önlenmesi: Ulusal Uzlaşı Raporu. Klimik Derg 2015; 28: 2-34.
6. Wheat LJ, Allen SD, Henry $M$ et al. Diabetic foot infections: bacteriologic analysis. Arch Intern Med 1986; 146: 1935-40.

7. Bridges RM, Deitch EA. Diabetic foot infections. Surg Clin North Am 1994; 74: 537-55.

8. Schaper NC. Lessons from Eurodiale. Diabetes Metab Res Rev 2012; 28: 21-26.

9. Prompers L, Schaper N, Apelqvist J et al. Prediction of outcome in individuals with diabetic foot ulcers: focus on the differences between individuals with and without peripheral arterial disease. The EURODIALE Study. Diabetologia 2008; 51: 747-55.

10. McGee SR, Boyko EJ. Physical examination and chronic lowerextremity ischemia: a critical review. Arch Intern Med 1998; 158: 1357-64.

11. Demir Y, Demir S, Gökçe Ç. Diabetik ayak: fizyopatolojisi, tanısı ve rekonstrüksiyon öncesi tedavisinde güncel yaklaşımlar. Kocatepe Med J 2004; 5: 1-12.

12. Apelqvist JA, Lepäntalo MJ. The ulcerated leg: when to revascularize. Diabetes Metab Res Rev 2012; 28: 30-35. 